\title{
CONSEQUENCES OF INCOMPLETE REASONING IN COURT ORDER FOR COVERT MEASURES
}

\author{
Željko Karas, PhD, Associate Professor \\ Police College, Ministry of Interior \\ Av. Gojka Šuška 1, HR-10000 Zagreb \\ zkaras@fkz.hr
}

\begin{abstract}
After several decisions of the European Court of Human Rights (ECtHR) against Croatia because of incomplete reasoning in a court order for covert measures (cases Dragojević, Bašić, Matanovic and Grba), statutory regulations were not amended, but in the case-law an attempt was made to change the interpretation regarding exclusion of gathered evidence. The author researches this issue in order to determine the trends in the Supreme Court's (SC) interpretation, and impact of the ECtHR case-law over the past 12 years $(N=67)$. The results show that for a long time the SC has argued that a deficiency in reasoning is an irregularity, but not as serious to lead to exclusion of covert recordings and other evidence.

One of the SC chambers issued a decision in 2017, which it called "the revision", in which it expressed a different view that it was necessary to exclude all evidence gathered using incomplete court order, referring to some rules in few ECtHR decisions. The author therefore analyses the ECtHR's rules on the judicial review, the exclusion of illegal evidence, and other available safeguards to reduce court arbitrariness. The results indicate that exclusion of evidence is not primary remedy for improving lawfulness of procedure. Problems with compliance with the Convention law could continue to arise due to a lack of other appropriate safeguards in Croatian legislature.
\end{abstract}

Keywords: covert evidentiary measures, court order, reasoning, deficiency, ECtHR

\section{INTRODUCTION}

Special evidentiary actions are very intense interference in the fundamental rights of citizens, and that is the main reason why they are regulated in much more detailed manner and with more safeguards compared to classic evidence gathering measures. One of statutory rules in Croatia requests that they can be determined solely by a court order (authorisation), which must, among other conditions, con- 
tain a reasoning (explanation) of grounds for suspicion and grounds for subsidiarity (Article 332 of the Criminal Procedure Act - CPA). ${ }^{1}$ The purpose of such provisions with many prerequisites is to reduce the arbitrariness and discretion of authorities and to protect the defendant's rights.

It is not explicitly prescribed in the Article 335(5) CPA that the violation of rule on court order reasoning leads to exclusion of evidence. For many years, the courts didn't exclude evidence. Even though some court decisions have sought to differ from this long existing interpretation, they had difficulties in finding legal basis in domestic law, and tried to refer to international level. The aim of this research is to conduct a more systematic analysis of changes in domestic practice and to determine the impact of decisions delivered by the European Court of Human Rights (ECtHR).

Covert investigative actions have so far been designated with different legal terms in Croatian legislation and they are currently referred to as special evidentiary actions. These actions include: surveillance and recording of communications, monitoring of computer data, surveillance and recording of premises, surveillance and recording of persons and vehicles, undercover investigator, simulated purchase or sale, simulated business and surveillance of delivery (Article $332 \mathrm{CPA}$ ).

This issue is very important for crime investigation. Police often initiates proceedings for approving covert evidentiary measures. After preparing necessary documentation and submitting the motion, the state attorney drafts the request and then the court makes prior judicial control and issues the order or refuses the request. If the judge of investigation refuses to issue an order, it is the judicial panel who shall make a final decision. There is a particular problem for police when it prepared a large documentation that justifies the required level of suspicion and supports the conclusion that other actions would not be successful, but a court did not include it in the reasoning of its written order.

Although an existence of satisfactory level of facts at the time of issuance of the court order, or providing grounds for suspicion, could be subsequently verified, one decision of the Supreme Court of the Republic Croatia (SC) did not widen possibilities to check reasoning, but instead recommended exclusion of all evidence collected by covert actions. That particular decision was called "the revision". ${ }^{2}$ Given that the inadmissibility of evidence is the ultimate measure, espe-

Criminal Procedure Act (Zakon o kaznenom postupku), Official Journal no. 152/08, 76/09, 80/11, $121 / 11,91 / 12,143 / 12,56 / 13,145 / 13,152 / 14,70 / 17,126 / 19$

2 Case SCRC (Supreme Court of the Republic Croatia), I Kž-Us 116/17, 5 November 2017. A revision is unknown term in Croatian criminal procedure law. Despite this, the decision is emphasising that it 
cially concerning credible materials such as recordings and photos are, the goal of this research is to analyse the interpretations about exclusion of evidence as a legal remedy in cases of inadequate reasoning of the court order on special evidentiary actions.

This issue has been of great relevance for years so it is rather strange that so far there was no scientific discussion or domestic publications on this important topic. Problem of insufficient reasoning did not attract reflections in foreign literature either. Some authors are describing requirement that a judgment should be reasoned, or they are explaining its main standards, but the reasoning of a court order is not commented. ${ }^{3}$ The Case Dragojevic is mentioned in few sources but without wider elaboration, ${ }^{4}$ while in some other publications no judgments have been mentioned from this field at all. ${ }^{5}$ Therefore, this research also involves insight and selection of relevant ECtHR case-law.

The paper analyses evolution of interpretation in the case-law over last 12 years. For the research presented in this paper, a sample of 67 decisions that have been delivered by the SC in the period from 2008 to the end of 2019 was collected. All the decisions were dealing with the issue of insufficiently extensive reasoning in a court order on special evidentiary actions. One of the goals of the research is to determine the period during which views of some SC chambers have been changed, and to determine the extent to which the ECtHR practice has influenced those changes. Besides that, the research included some additional issues, which shall be analysed in a separate study, as well as a number of decisions on this issue delivered by the Constitutional Court of Republic Croatia.

is making "the revision" of previous interpretations of the SC. The revision is an extraordinary remedy in some other branches of law. Some subsequent SC decisions are referring to the decision as "the revision" too; Case SC, I Kž 373/17, 12 September 2017

3 Trechsel, S.; Summers, S., Human Rights in Criminal Proceedings, Oxford University Press, Oxford, 2005, p. 106; Dijk, P. van; Hoof, G. J.; Van Hoof, G., Theory and Practice of the European Convention on Human Rights, Martinus Nijhoff Publishers, Hague, 1998, p. 428; Reid, K., A Practitioner's Guide to the European Convention on Human Rights, Sweet and Maxwell, London, 2011, p. 237

4 Müßig, U., Reason and Fairness: Constituting Justice in Europe from Medieval Canon Law to ECHR, Legal History Library, Brill, Boston, 2019, pp. 443, 446; Gerards, J., General Principles of the European Convention on Human Rights, Cambridge University Press, Cambridge, 2019, p. 216

5 Brems, E.; Gerards, J., Shaping Rights in the ECHR: The Role of the European Court of Human Rights in Determining the Scope of Human Rights, Cambridge University Press, Cambridge, 2014; Flogaitis, S.; Zwart, T.; Fraser, J., The European Court of Human Rights and its Discontents: Turning Criticism Into Strength, Edward Elgar Publishing, Cheltenham, 2013 


\section{RESEARCH SAMPLE AND BASIC DATA}

\subsection{Sample in general}

The SC case-law was collected by combining multiple types of searches using keywords in official database. The search was conducted by combining the keywords "reasoning" and "court order", as well as legislative terms for particular covert investigative actions as they are designated in the CPA. In this manner, over a hundred decisions were collected and each one of them was reviewed individually in order to make a selection of decisions which actually meet the research objectives. In addition, the court database was searched by the labels of particularly important decisions in order to find out to what extent and in which concrete cases those decisions were cited.

The research pointed out 67 decisions in which the court ruled on the (in)sufficiency of the reasoning contained in the court order on special evidentiary actions. Among those decisions, 53 were from the "I Kz Us" register, which refers to cases where proceedings are initiated under special USKOK (State Prosecutor's Office for the Suppression of Organized Crime and Corruption) legislation aimed to supressing organised crime and corruption. Such cases represented approximately $79 \%$ of all cases gathered in the sample. These were mostly complex cases, and the process of gathering evidence by using ordinary investigatory action was very difficult. In those cases, covert measures were actually necessary to gather evidence that could not otherwise be collected because of clandestinity of crimes. Key incriminating activities that constitute offences could be committed in a very short time by a verbal conversation, a secret message by communication device, or any other concealed modus operandi without producing any visible physical evidence that could point to organisers on higher level in the criminal network.

\subsection{Type of offenses}

Analysis of the type of criminal offenses covered by the sample, shows that most of them relate to various forms of narcotic drug trafficking or smuggling (14 cases). This offence is followed by abuse of service or authority committed by officials (9 cases), receiving or giving bribe (8 cases) and certain forms of participation in organised crime (8 cases), and various other offenses at a lower frequency. This situation corresponds with data from previous category confirming that these are complex crimes.

For the most part, investigation of such crimes do not start with the common victim as initial source of detection. In these types of criminal offenses, all stages of crime investigation are different than traditional types of criminal offenses, and 
therefore it is easier to substantiate conclusion on subsidiarity. Besides that, these offenses are very rare compared to other types of crimes. Exclusion of evidence for such offenses may have negative effect on confidence of citizens in judiciary.

\subsection{Type of covert investigative actions}

The sample data indicate a very high incidence of communication surveillance, with other covert actions occasionally used. In 48 covered decisions, such surveillance was used, representing about $72 \%$ of the sample. This means that in most of the cases, constitutional rights related to privacy of communications were affected.

Looking from the position of crime investigation goals, executing of communication surveillance can take months and can be very challenging in terms of listening to recordings, making recording and transcripts, interpretation of terms, selection of incriminating statements, translation, analytics and many other accompanying actions. In connection with the data showing that these criminal offenses are very rare, and that such covert actions cannot be carried out very frequently, it follows that there is not a simple possibility of repeating the same evidence by any other investigatory actions if key evidence is excluded.

\subsection{Frequency of decisions in certain periods}

Decisions are divided into three groups to make it feasible to observe their frequency over main periods defined by key decisions. The first group of decisions was delivered by 2015 when the first ECtHR decision on this issue against Croatia was declared (Case Dragojevic). ${ }^{6}$ Up to that year, a total of 24 decisions were found. The second group are decisions from 2015 to mid-2017 when "the revision" was made by one SC chamber, ${ }^{7}$ with 8 decisions found in that group. The revision decision was delivered in the period when Dragojević judgment was followed by ECtHR decisions in the Case Bašić in late 2016, ${ }^{8}$ and in the Case Matanović in early 2017. ${ }^{9}$ After those decisions a judgment in the Case Grba was delivered. ${ }^{10}$ This indicates that decision-making of the SC could be critically influenced by these ECtHR decisions. The third group consists of decisions beginning with "the revision" decision until the end of 2019, and covers a total of 25 decisions.

\footnotetext{
6 Judgment Dragojević v Croatia, no. 68955/11, 15 January 2015

7 Case SCRC, I Kž-Us 116/17, 5 November 2017

8 Judgment Bašić v Croatia, no. 22251/13, 25 October 2016

$9 \quad$ Judgment Matanović v Croatia, no. 2742/12, 21 February 2017

10 Judgment Grba v Croatia, no. 47074/12, 23 November 2017
} 
This development shows that the third group covers the most decisions, although it is not a long period of time since it lasts only about two years. In contrast, the first period is almost three times longer lasting (about six years) but it does not involve as many decisions. Similarly, the period of approximately two years between the first ECtHR decision and the revision decision also does not cover as many decisions as the post-revision period. Total number of SC decisions in certain period implies that this became important issue in domestic law, and that this fact could have impact on the ECtHR to use rigorous scrutiny in Croatian cases.

It seems that here could be some kind of interaction identified. The ECtHR's first decision has incited higher number of appeals on this issue, and on the other side, higher number of appeals is raising importance of this issue and provokes stricter scrutiny. Appealing on the legality of the evidence is the simplest form of defence in criminal procedure, so that fact maybe attracted more complaints too.

\section{FREQUENCY OF INTERPRETATION IN THE SC CASE-LAW}

\subsection{The SC viewpoint on the exclusion of evidence}

Observed sample contains a total of 33 decisions in which the SC expressed a view that even if the reasoning in the court order was defective, or if the reasoning was not completely specified in the court order, this very fact should not affect the admissibility of evidence. In all of those cases, the court explained that there was no legal basis to exclude evidence for such a minor ground as the insufficient reasoning of the court order is. It is a very large proportion (49\%) of decisions in which the court expressed its view on admissibility of evidence gathered on the basis of the incomplete court order. In 28 decisions, the court did not rule on whether a defect in the court order could lead to the illegality of the evidence, but rather discussed other issues on court order reasoning (42\%).

The opposite view is that a failure to write (sufficient) reasoning in an order constitutes a violation that should lead to the exclusion of the evidence collected. Such view is represented in only 6 decisions in the entire sample (9\%). In explaining such position, the court often referred to the SC "revision" or cited some of the rules from the ECtHR's decisions on the impossibility of retrospective justification. Data shows that most of these decisions were delivered after 2017 so it seems they are trying to make a new path in the case-law.

\subsection{The SC's interpretations by the periods}

In the following part of the analysis, the interpretations on exclusion of evidence were divided in key periods. In the first group of 24 decisions delivered in the 
period between 2008 and 2015, in 19 decisions the SC expressed that a defective order should not lead to unlawfulness of evidence. Such decisions cover about $80 \%$ of that period. During this period, only one decision was stating opposite interpretation that evidence should be inadmissible because of an irregularity in the reasoning of a court order. This single decision was pronounced at the beginning of the observed period (in 2009) and there were no similar decisions for a long period afterwards. It is possible that this decision was made as a result of the initial uncertainty as to direction in which the interpretation could head. Two decisions from this group did not express any view on this issue.

The situation is very similar in the period after mid-2015 to 2017 , in which the court delivered a total of 18 decisions. In 10 decisions the court reached a conclusion on whether the deficiency could lead to exclusion of the evidence (56\%), and in 8 decisions no conclusion was delivered on this issue. All 10 decisions expressed the interpretation that there was no need to exclude evidence. There is not a single decision in this group that would express a contrary view, indicating that the court probably thought that other legal remedies could be used when it came to minor irregularities in the court order.

In the third period, 25 decisions were delivered since 2017 when the SC issued a revised opinion. There are 5 decisions in this group representing a view that evidence should be excluded. That accounts for $20 \%$ of the group. However, in 16 decisions none of position was presented on the said issue. It is important for the goal of analysis that in this period there are still different decisions expressing quite the opposite view ( 4 decisions; $16 \%$ of this group). In those decisions court argued that there was no need to exclude evidence just because of an irregularity in the reasoning of the court order, which means that such views did not disappear after the SC revision decision. These results indicate that the revision does not necessarily mean a harmonization of the case-law in the field of criminal procedure law, concerning it is not familiar in this branch law and this issue should be wider researched too.

\subsection{Content of appeals}

In total sample of 67 decisions, most of the defendants' complaints expressed a remark that the reasoning was insufficient (11), whereas after 2015 this ground of appeal was expressed only twice. The most common allegations in this period were that a court's reasoning literally copied allegations from the state attorney's request, or that the grounds stated in the court order were contradictory. This situation indicates that in the observed sample there was a change in the allegations in the post-2015 period. Appeal allegations do not necessarily indicate that there 
has been a change in the manner in which court errors are perceived, because this depends on the quality of the court orders too.

\section{FREQUENCY OF ECTHR CASE-LAW IN DECISIONS OF THE SC}

\subsection{The ECtHR case-law in the SC decisions}

The SC referred to ECtHR practice in a very small number of cases before 2015. In this period, there were only two decisions delivered in 2008 and 2009. The decisions do not specify certain ECtHR judgments, but only few provisions of the Convention law (Articles 6 and 8). Such short reference is common in the SC case-law, given that it usually has brief decisions. In both of these decisions which are invoking Convention law, the court expressed a view that failure to state reasons in the court order should not lead to the exclusion of evidence collected. ${ }^{11}$

Between 2015 and 2017, 4 decisions were found in which the SC expressed compliance with the ECtHR standards, but these were also short references only. Data show that in the period from 2015 to 2017 , the number of ECtHR references was doubled compared to the previous period, but there is still a low representation in the total sample (around 6\%). In one decision, the court merely referred to $\mathrm{Eu}-$ ropean standards in half of sentence, ${ }^{12}$ or court briefly cited the judgment Dragojevic, ${ }^{13}$ or more extensive quotes the decision of Dragojevic,,${ }^{14}$ or citing particular provisions of the Convention. ${ }^{15}$ In the next three decisions, the SC also reiterated the view that irregularities in the reasoning of court order did not lead to the illegality of collected evidence (recordings etc.).

In the period following the $2017 \mathrm{SC}$ revision decision, the court delivered 7 decisions invoking certain aspects of the Convention law, which is about $10 \%$ of the entire sample. Although the level represents an increase over this period, most of these decisions only briefly list references too. These decisions were following the $\mathrm{SC}$ revision decision in a conclusion that the evidence should be excluded as illegal. ${ }^{16}$ It is very interesting that during this period one decision of the SC was delivered, in which the court decided completely contrary to the 2017 SC revision decision and stated that irregularities in the court order should not lead to the illegality of the evidence, and evaluated this interpretation in accordance with the

\footnotetext{
11 Case SCRC, I Kž 61/09, 3 February 2009; Case SCRC, I Kž 116/08, 1 April 2008

12 Case SCRC, I Kž-Us 148/15, 22 December 2015

13 Case SCRC, I Kž-Us 97/16, 12 October 2016

14 Case SCRC, I Kž-Us 131/16, 17 November 2016

15 Case SCRC, I Kž-Us 59/16, 25 October 2016

16 Case SCRC, I Kž-Us 58/18, 26 September 2018; Case SCRC, I Kž-Us 165/17, 8 February 2018, etc
} 
Convention standards too. ${ }^{17}$ There were few more decision of that kind but they did not refer to the Convention law.

This situation indicates that there are conflicting views about the same Convention standards, what urges a need to clarify which Convention rules govern this area. It would not be appropriate to use the ECtHR judicature as a general phrase to justify any interpretation. The limitation of the above data is that the Convention practice can influence the opinion of individual judges, although they do not explicitly invoke any reference.

\subsection{Frequency of the ECtHR case-law in appeals}

The share of the ECtHR's references among defendants' complaints was analysed too. In only four cases (less than 6\%) appeals were referred to the Convention judicature. Direct reference to the judicature in the appellate allegations was very rare, indicating that the ECtHR case-law was not represented at a high level. One case is from 2016, two from 2017 and only one from 2018. ${ }^{18}$ No reference to any ECHR violation was made before 2015. Notwithstanding explicit reference, the increase in appeals indicates that this has become a significant issue thanks to the influence of ECtHR law.

\section{DISCUSSION ON THE SC CASE-LAW}

\subsection{Estimation of the seriousness of violation}

In the 2017 revision decision, one SC chamber concluded that the irregularity in a court order constitutes breach of such gravity that collected evidence should be excluded similarly as in the cases of some other more serious violations defined in international law. ${ }^{19}$ In the earlier case-law, the SC stated that errors in reasoning of court order are irregularities, but they are not as serious as other enlisted statutory violations. The SC earlier held that there was no explicit legal provision which could lead to the illegality of evidence. ${ }^{20}$ Only for the most serious violations in the CPA it is explicitly prescribed that evidence should be excluded as illegal. The list is very extensive and it already includes more than forty violations in the

17 Case SCRC, I Kž -Us 134/17, 24 January 2018

18 Case SCRC, I Kž-Us 97/16, 12 October 2016; Case SCRC, I Kž-Us 53/17, 13 September 2017; Case SCRC, I Kž-Us 134/17, 24 January 2018; Case SCRC, I Kž-Us 77/18, 20 December 2018

19 Case SCRC, I Kž-Us 116/17, 5 November 2017

20 Turudić, I.; Pavelin Borzić, T.; Bujas, I., Evidence Obtained through Surveillance and Technical Recording of Telephone Conversations and Other Distance Communications in the Light of Article 8 of the European Convention on Human Rights, Rijeka Law Faculty Collected Papers, vol. 38, no. 1, 2017, pp. 595-630 
whole CPA, what makes domestic system one amongst widest in exclusion of illegal evidence. ${ }^{21}$ In the field of covert measures, these include violations such as performing measures without any court warrant at all, or exceeding deadlines, or instigating by undercover agent (agent provocateur), or if measures are directed on minor crimes, or other enlisted violations in the CPA. Concerning that, it is not unusual that the SC earlier concluded that irregularity is not so serious to be prescribed as unlawful evidence, ${ }^{22}$ or that there is no provision linking the unlawful evidence with the quality of the court order. ${ }^{23}$

One of the main objection to the revision is that it disproportionately equalizes violations of different severity. The revision is raising position of minor defects in the court order at the level of very serious violations, what leads to negative consequences in many other areas. Generally labelling all such covert actions as illegal could neglect the differences between a completely arbitrary or unfounded court order, from a substantially (materially) founded court order which just does not have complete reasoning written.

The SC observed in 20 decisions that the court has reviewed all materials and that it has agreed with the request, or it would otherwise refuse to issue an order. For example, the SC concludes that the issuance of a court order implies that the court accepted the request of state attorney with all facts stated therein, ${ }^{24}$ or that as soon as it issued the order it precludes that it accepted the request, ${ }^{25}$ or that the order undoubtedly implies that it accepted all facts, ${ }^{26}$ or that court would otherwise express dissent. ${ }^{27}$

Neither it was stated by the ECtHR that violation in the court reasoning was so serious to inflict negative consequences on the fairness of whole procedure. The $\mathrm{SC}$ revision is much rigorous than the Convention law. Violation of fairness was not found neither in the Case Dragojević nor in any other subsequent decision against Croatia (Matanović, Bašić, Grba). Compared to other examples of violations found in the ECtHR case-law in this field, Case Dragojević does not constitute serious injury like some other cases. This is not situation similar to the Case Szabo and Vissy $v$ Hungary where surveillance was performed without any judicial

21 Karas, Ž.; Štrk, D., Exclusion of Illegally Obtained Real Evidence in Comparative Law, Zagreb Law Review, vol. 2, no. 2, 2013, pp. 185-212

22 Case SCRC, I Kž-Us 7/17, 7 February 2017

23 Case SCRC, I Kž-Us 59/16, 25 October 2016

24 Case SCRC, I Kž 665/16, 19 December 2016

25 Case SCRC, I Kž-Us 101/18, 18 December 2018

26 Case SCRC, I Kž-Us 134/17, 24 January 2018

27 Case SCRC, I Kž-Us 69/10, 4 November 2010 
authorisation. ${ }^{28}$ The Court has consistently held that the use of evidence obtained in breach of the right to privacy does not render the proceedings unfair. ${ }^{29}$

In the Case Hambardzumyan a domestic court issued a court order for the execution of two covert measures that were not enlisted in the statutory provision at all. ${ }^{30}$ Even such violation did not have impact on the admissibility of evidence. Defendant was able to verify the credibility of the recordings and the ECtHR concluded that "secretly-taped material did not conflict with the requirements of fairness". ${ }^{31}$ Such violation had no influence on the admissibility of credible secret recordings, ${ }^{32}$ and the ECtHR position has not been altered in the much lighter cases against Croatia. ${ }^{33}$ Incomplete reasoning in the court order in the Case Dragojević and other cases is not as serious, for example, as violation in the Case Kvasnica $v$ Slovakia in which the court issued an order for surveillance against a lawyer, based on an oral request of officer, without any documents presented by police. ${ }^{34}$ Although the $\mathrm{SC}$ revision is referring to breach of international standards as an argument for exclusion of evidence (Article 10(2)2 CPA), it is clear that cases against Croatia are not containing such serious violation that should by European standards lead to the exclusion of evidence.

\subsection{Police response to serious violation in court order}

Exclusion of evidence adversely affects the investigatory work of authorities that have prepared materials for covert measures. If these bodies acted properly within the limits of their lawful authority, and if they fulfilled all legal preconditions for submitting covert actions, it is disputable what purpose the exclusion of evidence could achieve. Excluding of evidence does not have any effect on the court which was mistaken and endangered fundamental rights of defendant. If actions of police and state attorney were completely lawful, they did not contribute to violation of defendant's rights. A defective court order cannot nullify materials that existed

\footnotetext{
28 Judgment Szabó and Vissy v Hungary, no. 37138/14, 13 May 2014

29 Thommen, M.; Mojan S., The Bigger the Crime, the Smaller the Chance of a Fair Trial?: Evidence Exclusion in Serious Crime Cases Under Swiss, Dutch and European Human Rights Law, European Journal of Crime, Criminal Law and Criminal Justice, vol. 24, no. 1, 2016, p. 78

30 Judgment Hambardzumyan v Armenia, no. 43478/11, 5 December 2019, \$66

$31 \quad$ Ibid., $\$ 80$

32 Meese, J., The use of illegally obtained evidence in criminal cases: a brief overview, ERA Forum, vol. 18, no. 3, Springer, Berlin-Heidelberg, 2017, p. 307

33 Martinović, I.; Damir K., Nezakoniti dokazi: Teorijske i praktične dvojbe u svjetlu prakse Europskog suda za ljudska prava, Hrvatski ljetopis za kaznene znanosti i praksu, vol. 23, no. 2, 2016, p. 320

34 Judgment Kvasnica v Slovakia, no. 72094/01, 9 June 2009, \$87
} 
earlier. The SC revision does not explain why it would be necessary to disregard the use of results of lawful work?

It is very important to emphasise that in all of the cases covered in the sample, the SC did not find a single violation in police proceedings. Covert evidentiary actions are prepared in police units that have specific forms of supervision, precisely with an aim to reduce possible irregularities in their work. According to the results of the research, in 17 decisions the SC explicitly respected the lawful conduct of police in the preparation of material and expressed an opinion that there were extensive contributions of police and state attorney's files. Out of these cases, 5 were delivered after the SC revision, what shows that some SC chambers are still pointing out that short reasoning in court order does not mean that there was no appropriate material available. For example, in some decisions it was found that the court order was supported by police documentation, ${ }^{35}$ or that the request submitted to a court was fully substantiated, ${ }^{36}$ or that there was a very extensive police report before a court. ${ }^{37}$

The SC revision puts police in very compromising situation at the time when police receive a defective or questionable court order because it is not obvious that such order represents a criminal offence. If it is not obvious that court order is part of criminal offence, police have no authority to refuse a dubious court order, and it also have no ability to make an appeal. The police have no legal remedy on minor deficiencies in a court order. ${ }^{38}$ The police would be in position to execute an order although the revision decision considers it to represent a very serious violation. If this irregularity is as serious as it is evaluated by the revision decision, it could mean that maybe the police should not enforce such court order. A literal adherence to the viewpoint contained in the revision decision would mean that the police may be expected to respond in the same way as it would to substantial violations in a court order.

For example, if the police were to receive a court order with obvious intentional breaches, it would have a duty to report the unlawful work of judicial bodies. For example, in a hypothetical case where the court would arbitrarily issue an order for communication surveillance, contrary to all statutory provisions, police would not be able to join such illegal activity. For example, such illegality would be if a court order is delivered although a case is not a criminal offense at all, but it is only misdemeanour, and if the order was, for example, issued for apparently over-

\footnotetext{
35 Case SCRC, I Kž-Us 38/18, 16 May 2018

36 Case SCRC, I Kž-Us 58/18, 26 September 2018

37 Case SCRC, I Kž-Us 117/09, 26 September 2011

38 Case SCRC, I Kž-Us 98/09, 17 February 2010
} 
stepping duration of five or ten years, and if there was not any official request for issuing an order.

A remedy should not inflict damages to the interests of society by releasing perpetrators such as bribed officials or organised crime figures. If we could evaluate responsibility of police using the Convention case-law, we can see that in none of the aforementioned decisions against Croatia, the ECtHR did not state that police have violated any rule. For this reason, it is rational to consider that neither should the negative consequences be aimed at undermining police investigation results. Given that police are an executive body, it would be feasible to introduce additional monitoring measures by an authority that may have such authority, for example certain remedies could be invoked through the higher judicial authorities.

\section{SAFEGUARDS TO PREVENT ARBITRARINESS IN COURT ORDER}

\subsection{Legal remedies to improve lawfulness of court order}

\subsubsection{Judicial review}

Instead of excluding the evidence as suggested by the SC revision, ${ }^{39}$ it was more appropriate to reinforce some existing remedies and to add some new forms of solving problematic parts. It would be appropriate to use some remedies that could enhance review of a court order in earlier stages of procedure. Safeguards in procedures and supervision are necessary in democratic society. ${ }^{40}$ Secret surveillance is usually regarded as a measure that could restrict democracy, so maybe that feature surely has some impact on strict reasoning of the ECtHR.

In a number of decisions, the SC has taken the standpoint that a subsequent review may be conducted to determine whether the court order corresponds to the facts in records. Such scrutiny may be exercised, for example, by an indictment panel which has to determine whether a court order correctly reflects the situation in the file. Such view was expressed by the SC when it concluded, for example, that the indictment panel was required to verify the circumstances at the time of its issuing, ${ }^{41}$ or when the court may subsequently check whether the conditions existed at the time of issue. ${ }^{42}$

\footnotetext{
39 Case SCRC, I Kž-Us 116/17, 5 November 2017

40 Eskens, S.; van Daalen, O.; van Eijk, N., Standards for Oversight and Transparency of National Intelligence Services, Journal of National Security Law and Policy, vol. 8, no. 3, 2015, pp. 567

41 Case SCRC, I Kž-Us 116/16, 24 October 2016

42 Case SCRC, I Kž-Us 7/17, 7 February 2017
} 
The revision ignores judicial review as a remedy in earlier or later stages, naming it by a derogatory term "retroactive justification" instead of suggesting to improve its features. ${ }^{43}$ The ECtHR used a similar term because it wanted to emphasize that existing judicial control was flawed and should be improved rather than abolished. Court review cannot be rejected as a matter of principle. For example, in a hypothetical situation where the reasoning of the court order would include untrustworthy information, the court would subsequently have obligation to inspect all materials in order to compare facts in the file with facts stated in a court decision. Many remedies can review credibility or lawfulness during appeal proceedings.

\subsubsection{Strengthening supervision in certain stages of procedure}

It was possible to supplement legal provisions so that court orders would pass some additional scrutiny or checkpoints before being sent to police. Such additional checks could be carried out either obligatory or exceptionally at the request of certain bodies or defendant. Given that there is not a large number of court orders per year for secret surveillance nor other special evidentiary actions in domestic system, the obligation of a court panel or a higher court to check or validate each court order reasoning, should not impose an overload. Such measure would also help to remove issues on police responsibility if it is performing a questionable court order.

In comparative law there can be found various forms of subsequent action in order to correct irregularity. One example is when certain bodies have authority to correct mistakes found in court orders before sending them for execution. In the Case Kennedy $v$ The United Kingdom there is mentioned that subsequent supervision by a commissioner can use the powers of rectification. ${ }^{44}$

An example of safeguards is introduction of an additional appeal procedure that could be opened within a certain period after the targeted person has been officially informed that a covert measure has been completed. In some countries, such appeal could be submitted six months after a person has been officially noticed that a covert measure had finished, ${ }^{45}$ whether or not incriminating evidence has been gathered. In addition to these, there are various possibilities of introducing many other safeguards.

\footnotetext{
43 Case SCRC, I Kž-Us 116/17, 5 November 2017

44 Judgment Kennedy v The United Kingdom, no. 26839/05, 18 May 2010, \$149

45 Decision Weber and Saravia v Germany, no. 54934/00, 29 June 2006, \$49
} 


\subsection{The ECHR rules on certain legal remedies}

\subsubsection{Characteristics of judicial review}

The ECtHR is suggesting in its cases against Croatia that there should be introduced additional safeguards to enhance lawfulness of the proceedings. The ECtHR makes remark that authorities have not shown that there exist other forms of checks or appeals in the event of privacy violations. ${ }^{46}$ The ECtHR requires involvement of a priori or a posteriori review with an aim to ensure that covert measures are not ordered irregular. ${ }^{47}$

It is unusual that instead of reinforcing the weaker parts of procedure, the attention towards them has been neglected. For a judicial review in appeal proceedings, the ECtHR uses the term "retrospective justification" which clearly indicates that it does not consider them to be of appropriate quality. This is particularly evident when the ECtHR further states that such control cannot represent sufficient safeguard, because it opens a space to arbitrariness. ${ }^{48}$ The ECtHR remarks that check of lawfulness of evidence is only existing legal remedy in relation to a defective court order, and moreover, it is limited and does not check substantial issues. ${ }^{49}$

These remarks are central to the analysis of the ECtHR judgments, as they emphasize the importance of widening appeal process. The ECtHR appears to have concluded that a judicial review in domestic proceedings represents an automatic justification of omissions of lower courts. The ECtHR states that relevant domestic law, as interpreted by the courts, did not provide sufficient clarity and did not provide adequate safeguards against abuses, and that the procedure for ordering and monitoring was not fully in accordance with the requirements of lawfulness. ${ }^{50}$ Therefore, it is clear from decisions against Croatia that several factors contributed to the injury, what means one-sided approach could not be enforced effectively. The main role is being played by the lack of safeguards and insufficient judicial review, which finally led to unclear interpretations by higher courts.

\footnotetext{
46 "the Government have not provided any information on remedies - such as an application for a declaratory judgment or an action for damages“, Judgment Dragojević v Croatia, op. cit., note 6, \$100

47 Kusak, M., Mutual admissibility of evidence in criminal matters in the EU: A study of telephone tapping and house search. IRCP-series, vol. 53, Maklu, Antwerpen, 2017, p. 56, 57

48 Judgment Dragojević v Croatia, op. cit., note 6, $\$ 98$

49 "competent criminal courts limited their assessment of the use of secret surveillance to the extent relevant to the admissibility of the evidence thus obtained, without going into the substance of the Convention requirements“, Judgment Dragojević v Croatia, op. cit., note 6, $\$ 100$

50 Judgment Dragojević v Croatia, op. cit., note 6, \$101; Matanović v Croatia, op. cit., note 9, \$114; Grba $v$ Croatia, op. cit., note 10, \$86; Bašić v Croatia, op. cit., note 8, \$34
} 
In all decisions against Croatia, the ECtHR considers that a judicial review of lawfulness circumvented the obligation to provide a detailed reasoning at the time the order was issued..$^{51}$ If a judicial review of lawfulness would not be limited and if it could be focused on substantive issues, the ECtHR would probably accept it as a sufficient safeguard and would not consider it as an opportunity to circumvent the legal obligations.

Such context for the evaluation of judicial review is evident by comparison with other comparative law systems in which the ECtHR held quite the opposite conclusion that a judicial review is a satisfactory safeguard. The ECtHR has explicitly stated that judicial review may offer sufficient safeguards because it is impossible to disclose a covert action to a defendant at the time of its execution. ${ }^{52} \mathrm{~A}$ judicial review offered a sufficient safeguard against arbitrariness in similar case of covert movement surveillance. ${ }^{53}$

It follows that judicial review must be focused on certain fields, and it must have certain characteristics in order to be accepted as satisfactory. Breaches were seen in some other countries as well as in Croatia. For example, the ECtHR found in the Case Šantare that the domestic system did not provide an effective remedy. ${ }^{54} \mathrm{In}$ the Case Liblik it was found that the court made only superficial and declaratory statements in the court order. ${ }^{55}$ The ECtHR also concluded that the obligation to state reasons at the time of issuance of court order cannot be replaced by the possibility of justification at later stages of the proceedings when many other evidence is already collected. ${ }^{56}$

Sometimes it is hard to determine seriousness of a breach comparing some of the cases delivered against different countries, because of unclear criteria which are used. That guided some authors to conclusion that the ECtHR case-law is inconsistent. Some scholars have doubts if their system of safeguards could pass strict scrutiny of that kind. ${ }^{57}$ Some authors analysed ECtHR surveillance cases and divided them into two groups of low and strict scrutiny cases, with an aim to find connection with variables such as type of crime, means of interception, conviction

\footnotetext{
51 Judgment Dragojević v Croatia, op. cit., note 6, \$98; Matanović v Croatia, op. cit., note 9, \$114; Grba $v$ Croatia, op. cit., note 10, \$86; Bašić v Croatia, op. cit., note 8, \$34

52 Judgment Sommer v Germany, no. 73607/13, 27 April 2017, \$62

53 Judgment Uzun v Germany, no. 35623/05, 2 September 2010, \$72

54 Judgment Šantare and Labaznikovs v Latvia, no. 34148/07, 31 March 2016, \$62

55 op. cit. $\$ 137$

56 Judgment Liblik and Others v Estonia, no. 173/15 etc., 28 May 2019, $\$ 141$

57 Lindeman, J., Dragojevic t. Kroatië - annotatie, Jurisprudentie Bescherming Persoonsgegevens, no. 57, Utrecht, 2016, pp. 41, 44
} 
etc. Scrutiny by the ECtHR was low when terrorism was in case, but very strict when protesters against government or economic crime was at issue. The Case Dragojević falls into a group of strict scrutiny applied by the Court. ${ }^{58}$ Maybe some other factors contributed to strict scrutiny, such as large number of appeals on this issue in domestic system, what indicates a significance of a problem similar as in some other judgment like Ekimdzhiev. ${ }^{59}$ Very strict approach of the ECtHR in the Case Dragojević is explained by some scholars as consequence of a general impression about state surveillance left by the Snowden allegations. ${ }^{60}$

\subsubsection{Exclusion of collected evidence}

The ECtHR considers that the exclusion of illegal evidence is not a main tool for improvement of safeguards, so it is unclear why the SC revision has an opposite opinion and expects that it could solve all causes which are contributing to occurrence of the violations. Emphasis should be placed on other remedies to limit the discretion of certain authorities. ${ }^{61}$ Initiating a procedure to assess the legality of evidence or to seek its exclusion does not constitute a tool for improving the lawfulness. ${ }^{62}$ If covert measures were not accompanied by adequate safeguards, that opens a space for arbitrariness, ${ }^{63}$ regardless of the possibility of exclusion of unlawful evidence at later stages of procedure. Exclusion of evidence could be labelled as excessively rigid instrument if it does not achieve a right purpose.

The main disadvantage of exclusion is that it is not a remedy for protection of rights prior to the violation, nor it is a prompt remedy after the disputed covert

58 Malgieri, G.; De Hert, P, European Human Rights, Criminal Surveillance, and Intelligence Surveillance: Towards 'Good Enough' Oversight, Preferably But Not Necessarily by Judges, Cambridge Handbook of Surveillance Law, 2017, p. 8

59 After having noted some shortcomings, the ECtHR cited that more than 10.000 warrants were issued over a period of two years, what led to conclusion that „system of secret surveillance is ... overused ... which may in part be due to the inadequate safeguards", Judgment Ekimdzhiev v. Bulgaria, no. 62540/00, 28 June 2007, $\$ 92$

60 Sharpe, S., National Security, Personal Privacy and the Law: Surveying Electronic Surveillance and Data Acquisition, Routledge, London, 2019, pp. 49, 51 etc

${ }_{61}$ "Given the absence of specific regulations providing safeguards, the Court is not satisfied [...] to request the exclusion of its results as unlawfully obtained evidence met the 'quality of law' requirements described above“, Judgment Akhlyustin v Russia, no. 21200/05, 7 November 2017, \$45

62 "Given the absence of specific regulations providing safeguards, the Court is not satisfied that, as claimed by the Government, the possibility for the applicant to [..] request the exclusion of its results as unlawfully obtained evidence met the above requirements", Judgment Bykov v. Russia, no. 4378/02, 10 March 2009, $\$ 80$

63 "open to arbitrariness and were therefore inconsistent with the requirement of lawfulness", op. cit. $\$ 46$ 
action has been taken. ${ }^{64}$ Exclusion of evidence is applied later in criminal proceedings and it gives benefit to perpetrators only, but not to other persons against whom the same violation is committed and incriminating recordings or other evidence was not found. In a hypothetical case when a court order for surveillance would be issued contrary to statutory conditions and in excess of judicial authority, and no single evidence is found, exclusion doesn't have any effect. If no evidence of a serious crime is found because the target person had not committed it, a serious violation of privacy rights exits, but the person is unable to use exclusion of evidence as a respond to arbitrariness.

The ECtHR does not think that fairness would require the launch of exclusion of credible evidence, such as photos or recordings. ${ }^{65}$ The ECtHR has long favoured the credibility of evidence and considers it sufficient if the defendant had opportunity to verify authenticity of evidence. ${ }^{66}$ The SC revision decision states otherwise when it is emphasising that the ECtHR concluded that "the task is only to determine whether the defendant was able to question the lawfulness of any evidence before a domestic court" ${ }^{67}$ However, it is clear from the ECtHR's decisions that, in assessing the fairness of the proceedings it sought the opportunity to challenge the authenticity of recording, and not the lawfulness. ${ }^{68}$ The SC revision suggests that exclusion of evidence should be basic remedy by the Convention law, but such interpretation is not supported. The current situation does not seem to be in line with the ECtHR rules. That means violations can further appear despite this attempt. There has been applied too strict tool that does not cover all key issues that need to be addressed. Factors which contributed to the violation are just ignored.

\section{CONCLUSION}

The analysis shows that most of the time the SC had uniform interpretation about consequences of deficiencies in court order reasoning. The court held that omissions do constitute an irregularity, but they are not of such significance that recordings and other evidence collected through such covert actions should be excluded. Some decisions made references to the ECtHR standards in supporting

${ }^{4}$ Karas, Ž.; Štrk, D., Exclusion of Illegally Obtained Real Evidence in Comparative Law, Zagreb Law Review, vol. 2, no. 2, 2013, pp. 185-212

65 Krapac, D., Unlawful evidence in criminal procedure according to the case law of the European court of human rights, Zagreb Law Faculty Collected Papers, vol. 60, no. 6, 2010, pp. 1207-1240

66 Judgment Schenk $v$ Switzerland, no. 10862/84, 12 July 1988

67 Case SCRC, I Kž-Us 116/17, 5 November 2017

${ }_{68}$ Judgment Dragojević v Croatia, op. cit., note 6, \$132, Matanović v Croatia, op. cit., note 9, \$50, Bašić $v$ Croatia, op. cit., note $8, \$ 44$ 
this conclusion. The Convention law holds that breaches in this area are not causing negative effects on the fairness of the whole procedure. In no single decision against Croatia did the ECtHR found that the fairness of proceedings was impaired by the use of secret recordings as evidence in criminal proceedings. Besides that, the ECtHR made remark that the review of lawfulness of evidence constitutes a limited remedy without a substantive role.

Regardless of such viewpoint, one of the SC chambers issued a decision in 2017 naming it "the revision", and expressed a completely different standpoint on the exclusion of evidence, even though the statutory provisions were not changed in the meantime. Such a major change, which is contrary to a longstanding SC's case-law and is even more demanding than the Convention law, should have been substantiated on more extensive argumentation. Factors that contributed to occurrence of violations are neglected, and remedy that is recommended - the exclusion of evidence, cannot solve problems, but can only result in severe procedural consequences. The results of analysis indicate that earlier interpretation of the SC (which was dominant before 2017) was not contrary to the Convention standards, and that the newly proposed "revision" may be considered as too harsh and without targeted action.

The ECtHR pointed out several circumstances in Croatian cases that contributed to the violation of lawfulness in Article 8. The most significant factors were the lack of appropriate safeguards and the lack of adequate judicial review that could prevent circumvention of legal obligations. Compared to some similar cases from other countries, it seems that the ECtHR used rigorous scrutiny in Croatian cases, probably under the influence of high number of appeals on this issue. Intrusive actions are seen as a problem because they present potential danger to democratic society.

Exclusionary rule cannot replace other remedies that may provide more adequate, targeted reaction in case of procedural violations. The results of this research suggest that "the revision" should not be considered as a final interpretation of the Convention standards. Even after 2017 there are still interpretations, in certain SC chambers, that are contrary to "the revision". This inconsistency in the caselaw could be problematic in terms of adhering to ECtHR rules, probably until adequate additional safeguards would be fully provided at the statutory level. 


\section{REFERENCES}

\section{BOOKS AND ARTICLES}

1. Brems, E.; Gerards, J., Shaping Rights in the ECHR: The Role of the European Court of Human Rights in Determining the Scope of Human Rights, Cambridge University Press, Cambridge, 2014

2. Eskens, S.; van Daalen, O.; van Eijk, N. Standards for Oversight and Transparency of National Intelligence Services, Journal of National Security Law and Policy, vol. 8, no. 3, 2015, pp. 553-594

3. Flogaitis, S.; Zwart, T.; Fraser, J., The European Court of Human Rights and its Discontents: Turning Criticism into Strength, Edward Elgar Publishing, Cheltenham, 2013

4. Gerards, J., General Principles of the European Convention on Human Rights, Cambridge University Press, Cambridge, 2019

5. Karas, Ž., Attitude of the European Court for Human Rights Toward Unlawful Police Evidence, Pravni vjesnik, vol. 22, no. 1-2, 2006, pp. 116-126

6. Karas, Ž.; Štrk, D., Exclusion of Illegally Obtained Real Evidence in Comparative Law, Zagreb Law Review, vol. 2, no. 2, 2013, pp. 185-212

7. Krapac, D., Unlawful evidence in criminal procedure according to the case law of the European court of human rights, Zagreb Law Faculty Collected Papers, vol. 60, no. 6, 2010, pp. $1207-$ 1240

8. Kusak, M., Mutual admissibility of evidence in criminal matters in the EU: A study of telephone tapping and house search, IRCP-series, vol. 53, Maklu, Antwerpen, 2017

9. Lindeman, J., Dragojevic t. Kroatie - annotatie, Jurisprudentie Bescherming Persoonsgegevens, no. 57, Utrecht, 2016

10. Malgieri, G.; De Hert, P, European Human Rights, Criminal Surveillance, and Intelligence Surveillance: Towards 'Good Enough' Oversight, Preferably But Not Necessarily by Judges, Cambridge Handbook of Surveillance Law, Cambridge University Press, Cambridge, 2017, pp. 509-532

11. Martinović, I.; Damir K., Illegal Evidence: Theoretical and Practical Doubts in the Light of the Case Law of the European Court of Human Rights, Croatian Annual of Criminal Sciences and Practice, vol. 23, no. 2, 2016, pp. 311-338

12. Meese, J., The use of illegally obtained evidence in criminal cases: a briefoverview, ERA Forum, vol. 18, no. 3, Springer, Berlin Heidelberg, 2017, pp. 297-309

13. Müßig, U., Reason and Fairness: Constituting Justice in Europe from Medieval Canon Law to $E C H R$, Legal History Library, Brill, Boston, 2019

14. Newell, B.; Timan, C.; Koops, B., Surveillance, Privacy and Public Space, Routledge Studies in Surveillance, Routledge, 2018

15. Reid, K., A Practitioner's Guide to the European Convention on Human Rights, Sweet and Maxwell, London, 2011

16. Roca, J. G.; Santolaya, P., Europe of Rights: A Compendium on the European Convention of Human Rights, Martinus Nijhoff Publishers, Leiden, 2012 
17. Sharpe, S., National Security, Personal Privacy and the Law: Surveying Electronic Surveillance and Data Acquisition, Routledge, London, 2019

18. Thommen, M.; Mojan S., The Bigger the Crime, the Smaller the Chance of a Fair Trial?: Evidence Exclusion in Serious Crime Cases Under Swiss, Dutch and European Human Rights Law, European Journal of Crime, Criminal Law and Criminal Justice, vol. 24, no. 1, 2016, pp. 65-86

19. Trechsel, S., Summers, S., Human Rights in Criminal Proceedings, Oxford University Press, Oxford, 2005

20. Turudić, I.: Pavelin Borzić, T.; Bujas, I., Evidence Obtained through Surveillance and Technical Recording of Telephone Conversations and Other Distance Communications in the Light of Article 8 of the European Convention on Human Rights, Rijeka Law Faculty Collected Papers, vol. 38, no. 1, 2017, pp. 595-630

\section{LIST OF NATIONAL REGULATIONS, ACTS AND COURT DECISIONS}

1. Criminal Procedure Act, Official Journal No. 152/08, 76/09, 80/11, 121/11, 91/12, 143/12, $56 / 13,145 / 13,152 / 14,70 / 17,126 / 19$

2. SCRC, I Kž 116/08, 1 April 2008

3. SCRC, I Kž 373/17, 12 September 2017

4. SCRC, I Kž 61/09, 3 February 2009

5. SCRC, I Kž 665/16, 19 December 2016

6. SCRC, I Kž-Us 101/18, 18 December 2018

7. SCRC, I Kž-Us 116/16, 24 October 2016

8. SCRC, I Kž-Us 116/17, 5 November 2017

9. SCRC, I Kž-Us 117/09, 26 September 2011

10. SCRC, I Kž-Us 131/16, 17 November 2016

11. SCRC, I Kž-Us 134/17 24 January 2018

12. SCRC, I Kž-Us 134/17, 24 January 2018

13. SCRC, I Kž-Us 134/17, 24 January 2018

14. SCRC, I Kž-Us 148/15, 22 December 2015

15. SCRC, I Kž-Us 165/17, 8 February 2018

16. SCRC, I Kž-Us 38/18, 16 May 2018

17. SCRC, I Kž-Us 53/17, 13 September 2017

18. SCRC, I Kž-Us 58/18, 26 September 2018

19. SCRC, I Kž-Us 58/18, 26 September 2018

20. SCRC, I Kž-Us 59/16, 25 October 2016

21. SCRC, I Kž-Us 59/16, 25 October 2016

22. SCRC, I Kž-Us 69/10, 4 November 2010

23. SCRC, I Kž-Us 7/17, 7 February 2017

24. SCRC, I Kž-Us 7/17, 7 February 2017 
25. SCRC, I Kž-Us 77/18 20 December 2018

26. SCRC, I Kž-Us 84/16, 11 July 2016

27. SCRC, I Kž-Us 97/16, 12 October 2016

28. SCRC, I Kž-Us 97/16, 12 October 2016

29. SCRC, I Kž-Us 98/09, 17 February 2010

\section{ECHR}

1. European Convention for the Protection of Human Rights and Fundamental Freedoms, as amended by Protocols Nos. 11 and 14, 4 November 1950, ETS 5

2. Akblyustin v Russia, no. 21200/05, 7 November 2017

3. Bašić v Croatia, no. 22251/13, 25 October 2016

4. Bykov v. Russia, no. 4378/02, 10 March 2009

5. Dragojević v Croatia, no. 68955/11, 15 January 2015

6. Ekimdzhiev v. Bulgaria, no. 62540/00, 28 June 2007

7. Grba v Croatia, no. 47074/12, 23 November 2017

8. Hambardzumyan v Armenia, no. 43478/11, 5 December 2019

9. Kennedy $v$ The United Kingdom, no. 26839/05, 18 May 2010

10. Kvasnica v Slovakia, no. 72094/01, 9 June 2009

11. Liblik and Others $v$ Estonia, no. 173/15 etc., 28 May 2019

12. Matanović v Croatia, no. 2742/12, 21 February 2017

13. Šantare and Labaznikovs v Latvia, no. 34148/07, 31 March 2016

14. Schenk v Switzerland, no. 10862/84, 12 July 1988

15. Sommer $v$ Germany, no. 73607/13, 27 April 2017

16. Szabó and Vissy v Hungary, no. 37138/14, 13 May 2014

17. Uzun v Germany, no. 35623/05, 2 September 2010

18. Weber and Saravia v Germany, no. 54934/00, 29 June 2006 